The International Journal of Engineering and Science (IJES)

|| Volume || 6 || Issue || 5 || Pages || PP 32-40 || 2017 ||

ISSN (e): $2319-1813$ ISSN (p): $2319-1805$

\title{
Influence of Air-Fuel Mixtures and Gasoline - Cadoba farinosa forskk Bioethanol Fuel Mixtures on Emissions of a Spark - Ignition Engine.
}

\author{
Ejilah, I.R ${ }^{1}$. Gambo, B. A ${ }^{2}$. Dahuwa, $\mathrm{K}^{3}$. \\ ${ }^{I}$ Dept of Mechanical/Production Eng., Abubakar Tafawa Balewa University, Bauchi-Nigeria. \\ ${ }^{2}$ Dept of Mechanical/Production Eng., Abubakar Tafawa Balewa University, Bauchi-Nigeria Email: \\ ${ }^{3}$ National Center for Petroleum Research and Development, Abubakar Tafawa Balewa University Bauchi- \\ Nigeria
}

\begin{abstract}
This study presents the results of the influence of Cadoba farinosa forskk bioethanol-blended gasoline fuel samples and air-fuel mixtures on heat and emissions of a spark ignition (S.I.) engine. The effect of load variations on air-fuel mixture, exhaust gas temperature, heat loss in engine, and exhaust gas analysis were under-studied during an engine performance test $t$ with a TD110-115 S.I. engine, incorporated with an SV-5Q automobile exhaust gas analyzer, as recommended by SAE practice SAE J1312 test protocol, It was observed that the exhaust gas temperature, percent heat loss in engine, $\mathrm{CO}_{2}$ emissions increases with increase in load for all gasoline, and bioethanol blends- with GE4(19.42\%), GE6(25.58\%), GE8(25\%0, and GE10(23.25\%) exhibiting lower $\mathrm{CO}_{2}$ emissions than gasoline at maximum engine load. While, the variations of $\mathrm{CO}$ gases from GE2 to GE10 blends at maximum load are; 25\%, 25\%, 50\%, 41.66\%, and 33.33\% lower than that emitted from gasoline combustion. The sharp drop in CO emission at $2500 \mathrm{~g}$ engine load, suggests an improved combustion behavior at the load rating of least fuel consumption. Also at maximum load, GE2 to GE10 fuel samples were found to be $3.16 \%, 8.42 \%, 20 \%, 20 \%$, and $21.05 \%$ lower than HC emissions resulting from gasoline fuel combustion, in view of oxygenation ability of bioethanol in the blends. Hence, the higher heat loss recorded in bioethanol-blended fuel samples is attributable to lower calorific value, higher fuel density of the bio-ethanol blended fuel, the lowering of the air fuel ratio due to the oxygenation of the fuel, higher combustion temperature of the bioethanol-blended fuel samples. From the foregoing, it is could be concluded that ethanol derived from Cadoba farinosa forskk shrub, posses some inherent greenhouse gas mitigation potential in S.I. engines.
\end{abstract}

Keywords: Air-fuel mixtures, bioethanol, exhaust gases, emission, spark ignition engine.

Date of Submission: 01 May 2017 Date of Accepted: 17 May 2017

\section{INTRODUCTION}

The demand for energy around the world is increasing, with specifically the demand for petroleum fuels. World energy consumption is expected to increase to $180,000 \mathrm{GWh} /$ year by 2020 [1]. In view of the increasing consumption of petroleum fuels and the increasingly more stringent emission regulations meted out for its use, alternative fuel, biofuels, such as; ethanol and biodiesel and bio-gasoline is being explored to reduce fuel consumption and worrisome engine gaseous emissions regimen. In the recent past, many studies have been chronicled on the application of ethanol on diesel engine, which focus on the three aspects: application techniques of ethanol on spark ignition engine, fuel properties of ethanol-gasoline blends, and effects on the combustion and emission characteristics of ethanol-gasoline blends [2]. Ethanol is considered to be one of the most promising alternative renewable fuels. It can be fermented and distilled from sugarcane and grain, cellulosic materials, such as; wood, shrubs, agricultural solid wastes, coal, sweet sorghum etc. and also it has potential to reduce $\mathrm{CO}_{2}, \mathrm{CO}, \mathrm{HC}, \mathrm{NOx}$, and particulates emissions. The interest in the application of bioethanol derived from plant sources, as an alternative motor fuel has risen steadily around the world [3]. Little or no information exist on the use of Cadaba farinose forssk plant as a cellulosic substrate for bioethanol production. Gambo et al., [4], in a preliminary study of the fuel property characterization of ethanol derived from Cadaba farinosa forssk - the sahelian shrub found in northern Nigeria, has demonstrated a remarkable yield of 50.7\%. bioethanol via yeast fermentation method. The high ethanol yield from Cadaba farinosa forssk plant is an indication that the shrub presents a veritable source of bioethanol production compared to corn and cassava plant whose bioethanol yield falls within the range of about (35-42)\%, and (30-40)\%, respectively. Ethanol has some advantages over gasoline. These include; its high octane number and flame speed, high latent heat of vaporization and higher volumetric efficiency. It contains about 35\% oxygen that helps in complete combustion 
of fuel, and thus reduces harmful tailpipe emissions. However, in spite of these advantages, the limitation in technology, economic and regional considerations, adversely affected its extensive use as fuel in internal combustion engines.

Nonetheless, for overriding environmental consideration, the use of ethanol - gasoline blend is better than use of pure gasoline because of its renewability and reduced toxicity.. Several studies on the performance and emission characteristics of spark ignition engines, fuelled with pure gasoline and blended with ethanol, have been reported. The challenge compatibility with system components, phase separation, mobilization of sludge and particulates in fuel storage system is rife for higher volumetric concentration of ethanol in gasoline fuel blend, because a ethanol is known for its greater affinity for water than it does for gasoline. Overtime, without agitation, gasoline will be found floating on a layer of an ethanol/ water solution. It is clear that high concentrations of ethanol such, as E85, are certainly not compatible with traditional storage and dispensing systems $[5,6]$.

In view of stringent emission norms predicated on several international protocols, and the environmental impacts of alternative fuel for internal combustion engines, the influence of air-fuel ratio on engine performance, heat and gaseous emissions by utilizing different ethanol-gasoline fuel mixtures, is yet to be clearly understood. Hence, this study will report the effect of air-fuel mixtures and gasoline -Cadoba farinosa forrsk bioethanol blended fuel samples on heat and exhaust gas emissions of a spark ignition engine as the main thrust of the research objective.

\subsection{Ethanol production.}

\section{II.MATERIALS AND METHOD}

The production of the ethanol will be carried out by collecting Cadaba farinosa forssk shrubs from Bayara Market, in the southern out sketch of Bauchi metrolpolis, Nigeria. The shrub was dried at room temperature, milled and sieved into 40 mesh particle sizes to make it amenable to cellulosic hydrolysis. The resulting sucrose in the plant was then converted into glucose by saccharification, before converting the glucose to ethanol through yeast fermentation. The filtrate of the sample was distilled by heating it to $80^{\circ} \mathrm{C}$ in a fractional distillation apparatus for eight (8) hours. Ethanol was evaporated during this period, and later condensed in a receiver to produce roughly $95 \%$ alcohol [7].

\subsection{Preparation of fuel mixtures.}

A given volume of unleaded gasoline was blended with bioethanol derived from Cadaba farinosa forssk shrubs, in a 500ml beaker at GE2 (i.e. 2 percent by volume of the bioethanol with 98 percent by volume of gasoline), GE4, GE6, GE8, and GE10 volumetric proportions respectively. The mixtures were blended in a homogenizer by stirring vigorously for 10 minutes in a $500 \mathrm{ml}$ beaker at room temperature to ensure relative phase stability and homogenous consistency of the mixture on the short term measure. The choice of fuel mixtures (i.e. GE2- GE10) was adopted for this work for reasons that the federal fuel regulation in the U.S. has placed the maximum allowable ethanol concentration for use in vehicles designed to run on standard gasoline at $10 \%[6]$.

\subsection{Engine exhaust gases emission analysis.}

The TD 110-TD 115 single cylinder four-stroke internal combustion engine test bed incorporated with a hydraulic dynamometer was used to conduct the engine performance analysis (refer to Plate 1 and Table 1 for pictorial illustration and technical specifications). The engine exhaust emission tests of gasoline fuel sample (GF), GE2 (i.e. 2\% ethanol and 98\% gasoline by volumetric proportion), GE4, GE6, GE8 and GE10 fuel samples were conducted in accordance with standardized procedure of SAE practice SAE J1312 June 1995 for four-stroke compression and spark ignition engines [8]. The time taken by the engine to consume $8 \mathrm{ml}$ of the fuel, the air/fuel ratio, percentage heat loss and exhaust temperature were recorded for each fuel sample in the constant speed (i.e. $1500 \mathrm{rpm}$ ) and varying load (i.e. $500 \mathrm{~g}-3000 \mathrm{~g}$ range) engine test rig after every time interval of 20 minutes A benchmark test of engine emission analysis was conducted with GF samples for the purpose of comparison. As the engine was ran on GF sample for varying loading ratings (i.e.500-3000g), the corresponding engine exhaust emission concentration for oxides of nitrogen (NOx), unburned hydrocarbon (UHC), carbon monoxide (CO), carbon dioxide $\left(\mathrm{CO}_{2}\right)$, were measured with an SV-5Q Automobile gas analyzer in line with Non-Dispersive Infra -Red (NDIR) technique (refer to plate 2 and table 2 for equipment specifications). Subsequently, similar tests were also conducted with GE2, GE4, GE6, GE8 and GE10 blended fuel samples at varying engine load. The results were compared with the behavior of the benchmark gasoline test and analyzed accordingly. 


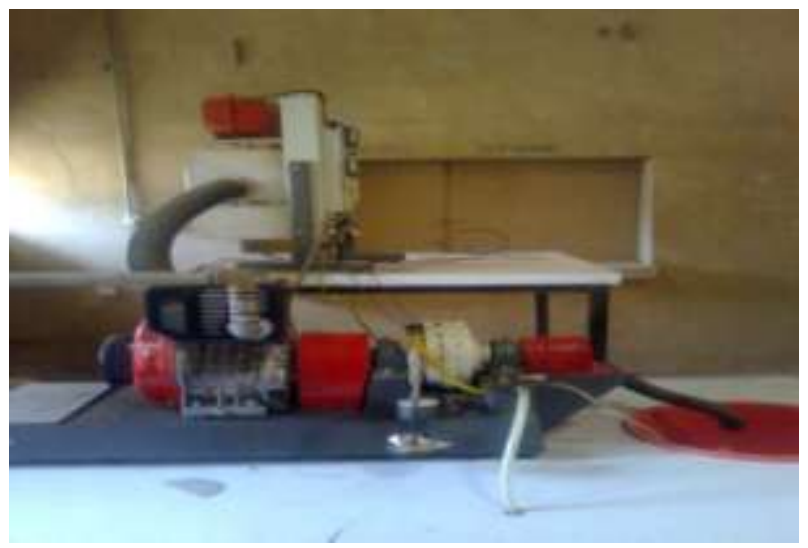

Plate 1. Engine test rig.

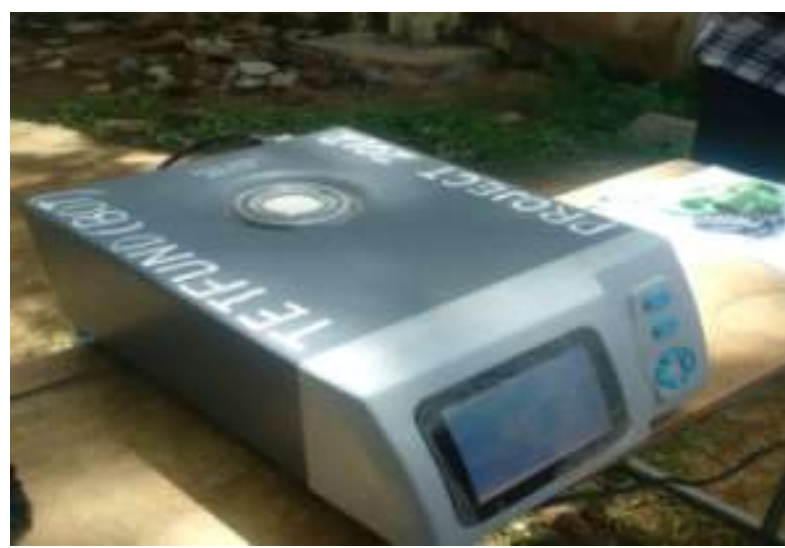

Plate 2. SV-5Q Automobile gas analyzer

Table 1: Technical specifications of engine test rig

\begin{tabular}{|l|l|}
\hline Type & Single cylinder, four stroke, air-cooled \\
\hline Bore $*$ Stroke & $65 \mathrm{~mm}$ x 70 mm \\
\hline Brake power & $2.43 \mathrm{~kW}$ \\
\hline Rated speed & $1500 \mathrm{rpm}$ \\
\hline Starting method & Manual cranking \\
\hline Compression ratio & $20.5: 1$ \\
\hline Net weight & $45 \mathrm{~kg}$ \\
\hline Manufacturer & TQ Educational Training Ltd \\
\hline Model & TD110-115 \\
\hline & \\
\hline
\end{tabular}

Source: [9].

Table 2. Specifications and technical parameters of SV-5Q Exhaust gas analyzer.

\begin{tabular}{|l|l|}
\hline Environmental conditions. & $-5 \sim 40^{\circ} \mathrm{C}$ \\
\hline Temperature: & $\leq 95 \%$ \\
\hline Humidity: & $60 \sim 106 \mathrm{kPa}$ \\
\hline Atmosphere pressure: & $\mathrm{AC} 220 \pm 10 \% ; 50 \mathrm{~Hz} \pm 1 \mathrm{~Hz}$ \\
\hline Power supply: & \multicolumn{1}{|l|}{$0 \sim 10000 \quad 10^{-6}(\mathrm{ppm}) \mathrm{vol}$} \\
\hline Measurement range & $0 \sim 10.0 \quad 10^{-2}(\%) \mathrm{vol}$ \\
\hline $\mathrm{HC}:$ & $0 \sim 20.0 \quad 10^{-2}(\%) \mathrm{vol}$ \\
\hline $\mathrm{CO}:$ & $0 \sim 20.0 \quad 10^{-2}(\%) \mathrm{vol}$ \\
\hline $\mathrm{CO}_{2}:$ & $0 \sim 5000 \quad 10^{-6}(\mathrm{ppm}) \mathrm{vol}$ \\
\hline $\mathrm{O}_{2}:$ & $0 \sim 1000 \mathrm{rpm}$ \\
\hline $\mathrm{NO}_{\mathrm{x}}:$ & $0 \sim 120{ }^{\circ} \mathrm{C}$ \\
\hline Speed: & \\
\hline Oil temperature & \\
\hline
\end{tabular}

\section{RESULTS AND DISCUSSION.}

The results of the air-fuel ratio, exhaust temperature, percentage heat loss and engine exhaust emission analysis for the varying engine loads were plotted against the concentration levels for carbon dioxide $\left(\mathrm{CO}_{2}\right)$ emissions, carbon monoxide (CO), unburned hydrocarbon (HC), and oxides of nitrogen (NOx), in Figs. 1- 7 respectively.

\subsection{Influence of fuel samples on air- fuel mixtures under varying loading conditions.}

Fig. 1 shows the variation of air-fuel ratio with load for all tested fuel samples. In S.I engines at a given speed the air flow do not vary with load, it is the fuel flow that varies directly with load. From the Fig. 1, it could be seen that as the concentration of bioethanol in the blended samples increases, the air fuel ratio reduces, but rises with increase in engine load. Air-fuel ratio values of ethanol blends are less than gasoline. It was observed that all tested fuel samples reached a maximum power output and torque at a higher than the stoichiometric AFR values (i.e. 18-25) for spark ignition engines. In this case, maximum power output is achieved at lean AFR mixture, therefore causing the engine to run at higher engine temperature and BSFC levels. The bound oxygen on the bioethanol molecules may also play a role in creating a leaner air-fuel ratio, which in turn leads to high air-fuel ratio than the stoichiometric values for all the samples tested [10]. 


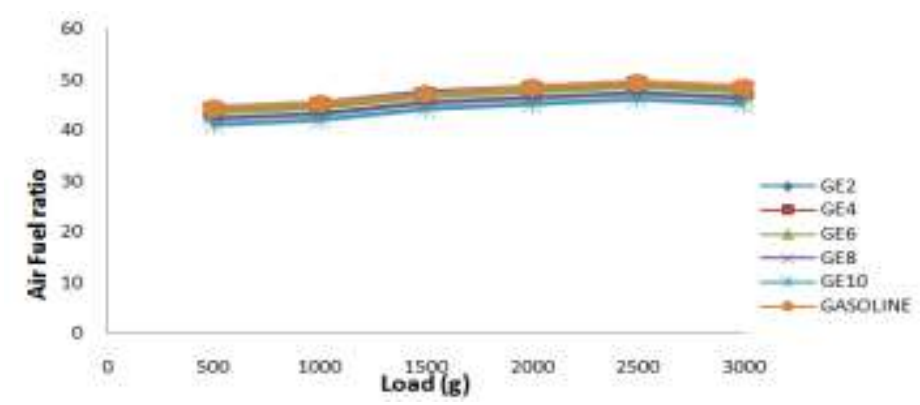

Figure 1. Air- fuel ratio of fuel samples under varying engine loading conditions.

\subsection{Influence of fuel samples on exhaust temperature.}

Fig. 2 shows the variation of exhaust gas temperature with load for various blends and gasoline. The exhaust gas temperature is, in fact, a vital pointer of cylinder temperature, and can also be applied to assess exhaust emission, particularly of NOx because NOx formation is often based on temperature [11,12]. The results illustrated in Fig. 2 shows that the exhaust gas temperature increases with increase in load for all blends, with GE2, GE4, GE6, GE8, and GE10 fuel samples found to be $0.47 \%, 0.94 \%, 1.17 \%, 4.93 \%$, and $6.1 \%$ higher than exhaust gas temperatures of combusted gasoline fuel at maximum engine load. At all loads, gasoline fuels samples were found to have the lowest exhaust temperature, and temperatures for various blends show an upward trend with the rise in concentration of ethanol in the blends, with GE10 and GE8 fuel samples presenting the highest exhaust temperature. This could be due to the higher heat loss of the blends, which are also evident from, their lower brake thermal efficiencies as compared to gasoline. The mean temperature increased linearly from $384^{\circ} \mathrm{C}$ at $500 \mathrm{~g}$ load to $452^{\circ} \mathrm{C}$ at $3000 \mathrm{~g}$ load condition for gasoline and all the blended samples. The increase in exhaust gas temperature with load is obviated by the fact that more amount of fuel was required in the engine to generate that extra power needed to take on the additional loading condition. Ethanol in fuel samples oxygenates the blends (refer to Table 3), and improves the combustion process, and consequently causes the exhaust gas temperatures to rise. In addition, air-cooled engines are known to run hotter than water cooled engines; this resulted in higher exhaust gas temperatures for the former than the latter. According to Ecklund, [13], the heat released usually occurs in the later part of the power stroke, and result in lower time for heat dissipation and higher exhaust gas temperatures. Hence, the use of ethanol in the fuel blends could raise the cylinder pressure to higher peak combustion temperature. Furthermore, a correlation could be established between exhaust temperature and brake power because; rise in combustion temperature brings about a commensurate increase in the pressure acting on the piston, for improved mechanical power output [9].

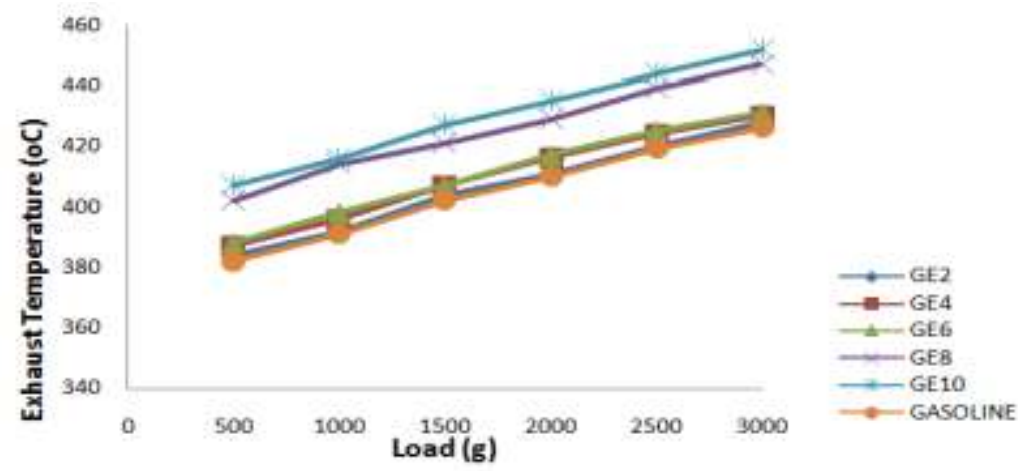

Figure 2. Exhaust temperature of fuel samples under varying engine loading condition.

Table 3. Proximate and ultimate analysis of gasoline and ethanol.

\begin{tabular}{|l|l|l|}
\hline \multicolumn{2}{|l|}{} & Gasoline \\
\hline Carbon & 0.86 & Ethanol $^{\mathrm{b}}$ \\
\hline Hydrogen & 0.128 & 52.20 \\
\hline Sulfur & 0.010 & 13.00 \\
\hline Nitrogen & 0.00 & 0.00 \\
\hline Oxygen & 0.00 & 0.00 \\
\hline Moisture & 0.00 & 34.84 \\
\hline Ash & 0.00 & - \\
\hline Density (kg/l) & $0.74-0.76$ & 0.00 \\
\hline GCV (Calculated) $\mathrm{mj} / \mathrm{kg}$ & 46.49 & 0.78 \\
\hline NCV (Calculated) $\mathrm{mj} / \mathrm{kg}$ & 43.623 & 30.15 \\
\hline
\end{tabular}

Sources: a. [14]; b.[15]. 


\subsection{Influence of fuel samples and air-fuel mixtures on engine heat loss.}

From Fig. 3, all gasoline-ethanol blends show evidence of higher heat losses in engines than gasoline fuel, with GE2, GE4, GE6, GE8, and GE10 fuel exhibiting a 2.63\%, 4.13\%, 5.46\%, 9.94\%, and $8.72 \%$ lower than gasoline fuel, in a trend similar to the influence of fuel samples on exhaust temperature under varying loading conditions. This could also be interpreted in terms of the relationship of the air fuel ratio in the combustion of fuel samples under varying engine loading conditions. That is as the load increases, more fuel and air is required for combustion to generate thermal energy to overcome the load. The higher heat loss recorded in the bioethanol- blended fuel samples is attributable to; the lower calorific (heating) value and relatively higher fuel density of bioethanol fuel samples (refer to Table 4 ), the lowering of the air fuel ratio due to the oxygenation of the blended fuel samples by ethanol, and higher combustion temperature of the blended fuel, consequently leads to increasing between the exhaust and ambient temperatures respectively, According to Plint and Partners [16], the heat unaccounted for by losses, is partly a function of the engine size. To this effect, for smaller engines considerable conductive and radiative heat losses are usually caused by inefficient combustion. Hence, high exhaust gas temperature and reduction in thermal efficiency with increase in blend is an evidence of increased heat losses

Table 4: Fuel properties of tested ethanol and gasoline samples.

\begin{tabular}{|l|l|l|l|l|}
\hline ASTM Test Protocol & Properties & $\begin{array}{l}\text { Cardoba faronisa } f . \\
\text { Ethanol }\end{array}$ & BDL Ethanol & Gasoline \\
\hline & & & & \\
\hline ASTM D97-93 & Density @ 20 ${ }^{\circ} \mathrm{C} \mathrm{g} / \mathrm{cm}^{3}$ & 789 & 7905 & \\
\hline ASTM D97-93 & Specific gravity & 0.789 & 0.7905 & 0.8 \\
\hline ASTM D 445 & Kinematic viscosity @ 40oC $\left(\mathrm{mm}^{2} / \mathrm{s}\right)$ & 34.52 & $29.7^{\mathrm{b}}$ & 0.757 \\
\hline ASTM D2015-85 & Calorific value $(\mathrm{mj} / \mathrm{kg})$ & 29.5 & 11.4 & 12.8 \\
\hline ASTM D 93-94 & Flash point $\left({ }^{\circ} \mathrm{C}\right)$ & 421. & 422.8 & -43 \\
\hline ASTM E659-78 & Auto Ignition temperarure $\left({ }^{\circ} \mathrm{C}\right)$ & - & 110 & 280 \\
\hline ASTM D2885 & Octane rating & -43 & 90 \\
\hline
\end{tabular}

Source: [4].

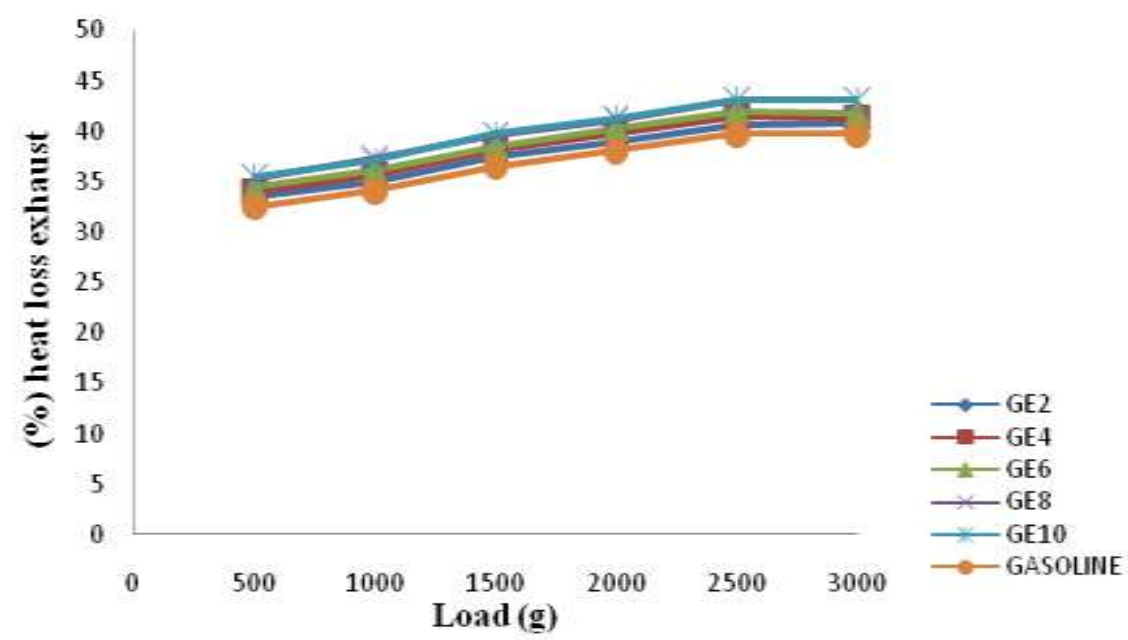

Figure 3. Heat loss of fuel samples under varying engine loading conditions.

\subsection{Influence of fuel samples and air-fuel mixtures on carbon dioxide emission.}

Fig. 4 shows the emission levels of carbon dioxide $\left(\mathrm{CO}_{2}\right)$ for various blends and gasoline. Test measurements reveal that while the $\mathrm{CO}_{2}$ emission profile increases with engine load, the $\mathrm{CO}_{2}$ emissions for GE2, GE4, GE6, GE8, and GE10 blends are $15.1 \%, 19.42 \%, 25.58 \%, 25 \%$, and $23.25 \%$ lower than $\mathrm{CO}_{2}$ emissions arising from gasoline combustion under different loading condition. The rising trend of $\mathrm{CO}_{2}$ emission with load is due to the higher fuel entry as the load increases., it could be seen from Fig. 1 that this trend demonstrated some similarities in behavior to the air fuel ratio for fuel samples under varying engine loading conditions, except for a slight peak at $2500 \mathrm{~g}$ engine load (refer to Fig. 4 ). The lower $\mathrm{CO}_{2}$ emissions for bioethanol -blended fuel samples could be $\mathrm{s}$ attributed to the fact that bio-ethanol is a lower carbon fuel owing to its lower elemental carbon to hydrogen ratio than gasoline fuel ( refer to Table 3) [17]. According to Carraretto, et.al. [18], the effect of bio-fuel on global greenhouse gas emissions through the life cycle of $\mathrm{CO}_{2}$ emissions is such that biofuel could cause a 50-80\% reduction in $\mathrm{CO}_{2}$ emissions compared to petroleum diesel. 


\subsection{Influence of fuel samples and air-fuel mixtures on carbon monoxide emission.}

Fig. 5 depicts the decreasing variation of $\mathrm{CO}$ exhaust emission in relation to incremental engine load. Carbon monoxide (CO) is an intermediate combustion product and is formed mainly due to incomplete combustion of fuel. If combustion is complete, $\mathrm{CO}$ is converted to $\mathrm{CO}_{2}$. If the combustion is incomplete due to shortage of air or low gas temperature, $\mathrm{CO}$ will be formed. It was observed that the engine emits more $\mathrm{CO}$ for gasoline fuel under varying load conditions is higher compared to other blends in the study. Alexandrian and Schwalm [19], had reported in an earlier work that different air-fuel ratios would clearly change $\mathrm{CO}$ emission, and using ethanol-gasoline-blended fuel would produce less CO and NOx than using gasoline, especially in rich condition. However, as the proportion of ethanol in the blend increases, the emission also decreases due to the higher oxygen content and lower carbon to hydrogen ratio in bioethanol compared to gasoline [18]. The variations of carbon monoxide emitted gases for GE2, GE4, GE6, GE8, and GE10 blends at an engine load of $3000 \mathrm{~g}$ are; $25 \%, 25 \%, 50 \%, 41.66 \%$, and $33.33 \%$ lower than that emitted from gasoline combustion The sharp drop in $\mathrm{CO}$ emission at the load of $2500 \mathrm{~g}$ suggests an improved combustion behavior at the load of least fuel consumption (i.e. lowest brake specific fuel and energy consumption values of the engine). These lower $\mathrm{CO}$ emissions in the blends may be due to their higher tendency for complete oxidation than gasoline during combustion. It could also be observed from Fig. 5 that the CO initially decreased with load and latter increased at higher load. This trend was observed for all tested fuel blends. Initially, at low load condition, cylinder temperature might be too low, which increases with loading due to more fuel injected inside the cylinder. At high load, more fuel is consumed leading to a relative lowering of the availability of oxygen for the combustion of the fuel, which results in slightly higher carbon monoxide. $\mathrm{CO}$ emission increases, as air-fuel ratio becomes higher than the stoichiometric value. The reduction of $\mathrm{CO}$ emission at an engine load of $2500 \mathrm{~g}$ is apparently caused by wide flammability - an inevitable outcome of accelerated flame speed in alcohol in the gasoline blends at high engine speeds [20]; and the' lean effect' generated by the oxygenated characteristic of ethanol, which consequently reduces $\mathrm{CO}$ emission $[21,22]$.

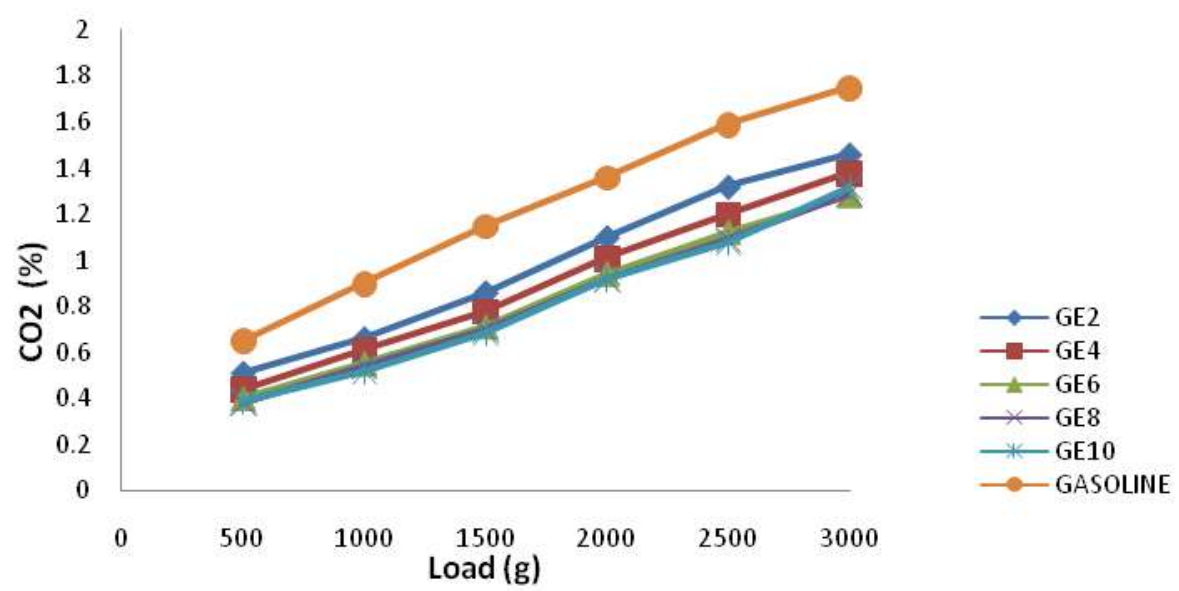

Figure 4. Carbon dioxide emission for fuel samples under varying loading conditions.

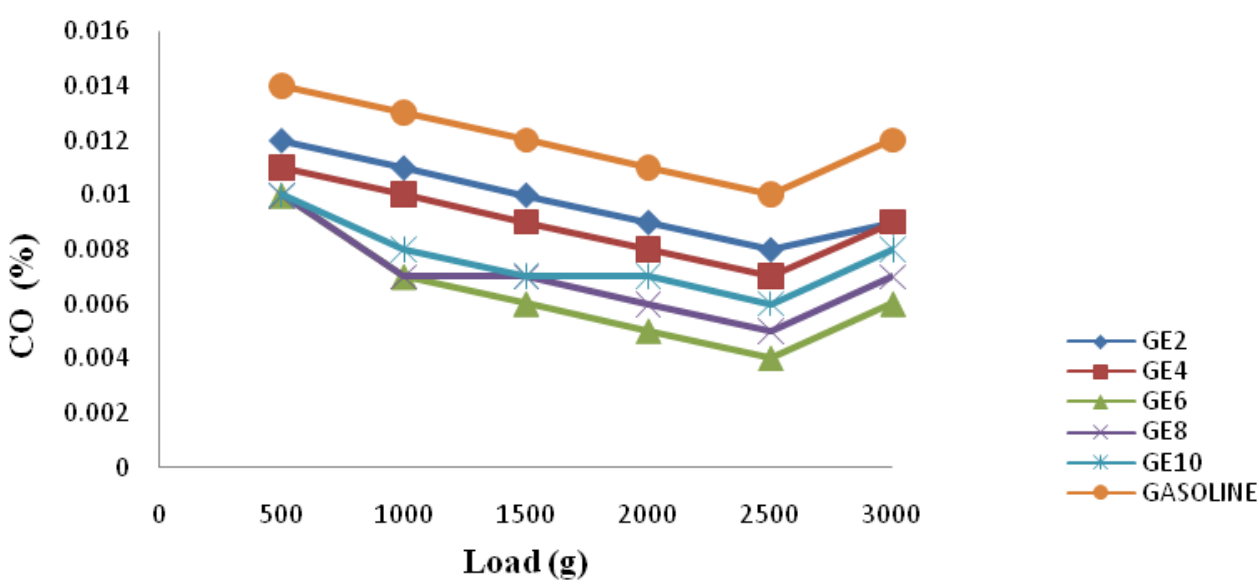

Figure 5. Carbon monoxide emission for fuel samples under varying loading conditions. 


\subsection{Influence of fuel samples and air-fuel mixtures on hydrocarbon emission.}

Fig. 6 presents the decreasing variation of un-burnt hydrocarbon (HC) exhaust emission with respect to the incremental engine load. $\mathrm{HC}$ in exhaust are a result of incomplete burning of the carbon compounds in the fuel. It could be seen from Fig. 6 that all blends have lower values than gasoline owing to higher combustion chamber temperature, which helps in cracking and faster burning [21]. It was observed that the HC emission decreased with increase in engine load (i.e. $500 \mathrm{~g}-2500 \mathrm{~g}$ ) and then increased slightly further with incremental load for all the samples at an engine load of 3000g.. At this maximum load, GE2, GE4, GE6, GE8, and GE10 blended fuel samples are 3.16\%,8.42\%, 20\%, 20\%, and 21.05\% lower than HC emissions resulting from gasoline fuel combustion. Even though, the trend is the reverse of the relationship between the air-fuel ratios and engine load respectively, it could be seen from Figs. 1 and 6 that as volumetric concentration of ethanol in the blends exhibit a reduction in air-fuel mixture and $\mathrm{HC}$ emission than gasoline respectively. The presence of oxygen in the ethanol blends aids combustion and reduces the $\mathrm{HC}$ emission considerably [23]. However, at higher loads the effects of viscosity have increased these emission levels for the blends due to poor fuel atomization. As the octane number of ester-based fuel is increased higher than gasoline, it tends to exhibits a shorter delay period and results in better combustion, leading to low HC emission [21].. Previous study have established that, laminar flame speed of alcohol is higher than gasoline [24], and this may assist complete combustion of alcohol-gasoline blend, and result in lower HC emission. Moreover, these emissions decrease as engine speed (and load) increases in all blends. At high speeds, the air-fuel mixture homogenizes to increase incylinder temperature. This condition in turn enhances combustion efficiency [25] .

\subsection{Influence of fuel samples and air-fuel mixtures on NOx and SOx emissions.}

It was observed in the course of experimentation, that the fuel samples and air -fuel mixtures seem to exert no influence on NOx and SOx emissions. This could be explained from the results of the proximate and ultimate analysis of gasoline and ethanol in Table 3. From the available information provided by Zoran et.al [14] and BEF [15] show that only negligible quantities of sulphur and nitrogen could be found in the fuel samples, and hence in combustion is unlikely to yield noticeable NOx and SOx emission levels. Eventhough, ethanol tends to exhibit higher oxygenation characteristics than gasoline, owing to its higher

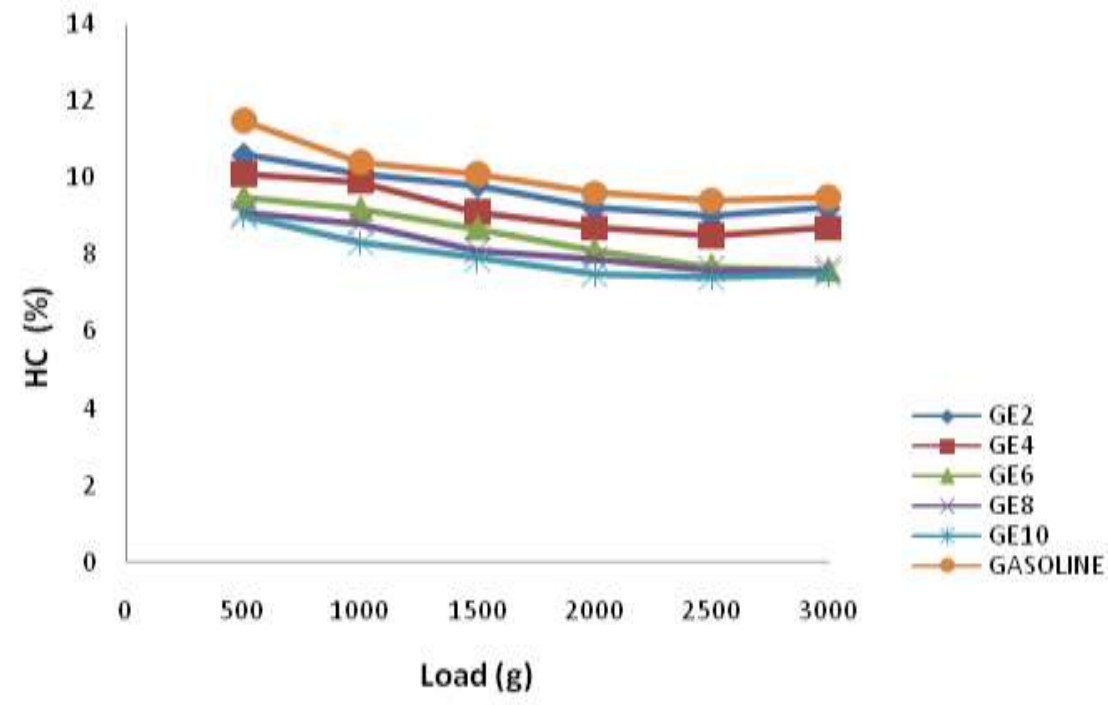

Figure 6. Unburnt $\mathrm{HC}$ emission of fuel samples under varying loading conditions.

content of oxygen molecules, it is nonetheless evident that NOx emission depended on the engine operating condition rather than the ethanol content [26]. Yacoub et al. [27] once suggested that oxygen content of ethanol increases peak in-cylinder pressure as well as NOx emission. Masum et al., [28] also observed that the generation of NOx in an engine is closely related to combustion temperature, oxygen concentration, residence time inside the combustion chamber, and it could be mentioned on specific terms that higher in-cylinder temperature has been identified as the core cause of thermal NOx formation of gasoline engine as nitrogen in the air oxidizes to form NOx [29]. From the foregoing it is become apparent that if no traces of NOx gases were recorded in the course of experimentation, the causal factor is traceable to either that; , the combustion (i.e. incylinder) temperature is not high enough, of the residence time inside the combustion chamber may not be long enough to cause NOx formation, despite the wider flammability and relatively higher combustion temperature (refer to Fig. 2) of ethanol in the blended fuel samples. 


\section{CONCLUSION}

From the foregoing, the following could be concluded from the study:

i. The air fuel ratio reduces, as the concentration of bioethanol in the blended sample and engine load increases.

ii. At all loads, gasoline fuels was found to have the lowest exhaust temperature and the temperatures for various blends show an upward trend with the increase in concentration of ethanol in the blends.

iii. Higher heat loss in bioethanol blended fuel samples could be attributed to the lower calorific value and higher fuel density of the bio-ethanol blended fuel samples, the lowering of the air fuel ratio due to oxygenation of the blended fuel samples by ethanol, and higher combustion temperature of the blended fuel.

iv. Higher $\mathrm{CO}_{2}$ gas emission could be attributed to the higher fuel entry (i.e. air-fuel ratio) with increase in engine load.

v. The lower CO emissions in the blends may be due to their higher tendency for complete oxidation than gasoline during combustion.

vi. The HC emission decreased with increase in engine load, and increases slightly further with incremental loading for all fuel samples at the engine load of 3000g.

vii. The absence of traces of NOx gases could be explained in terms of; lower combustion (i.e. in-cylinder) temperature, shorter residence time inside the combustion chamber, despite the wider flammability and relatively higher combustion temperature of ethanol in the blended fuel samples.

\section{ACKNOWLEDGEMENTS}

The authors are grateful to the management of Abubakar Tafawa Balewa University, Bauchi and Federal Polytechnic, Bauchi for allowing the use of their laboratory and workshop facilities in the course of the research work.

\section{REFERENCES}

[1]. S. Fernando, C. Hall, and S. Jha. NOx reduction from biodiesel fuels. Energy Fuels, Vol.20, 2006, 376-82,

[2]. A.C. Hansen, Q, Zhang, and P.W.L. Lyne. Ethanol-diesel fuel blends-a review. Bioresource Technology, 96(3), 2005, $277-285$.

[3]. S. Çaynak,, M. Guru, A. Bicer, A. Keskin, Y.Y Cingur.Fuel, 88(3), 2009.534-538.

[4]. B.A. Gambo, R.I. Ejilah and K. Dahuwa,. Fuel property characterization of ethanol derived from Cadaba 39arinose forssk shrub. Journal of Nigerian Institution of Mechanical Engineers, 6 (1), 2016, 92-98

[5]. Chemical and Physical Characteristics of Ethanol and Hydrocarbon Fuels, Module Two 2013.

[6]. TankSmart: Maine UST Operator Training Program. Iowa Department of Natural Resources. www.iowadnr.gov/land/ust/technicalresources/ethanol.html . Retrieved on the 10/03/2017

[7]. D.L. Nelson, and M.M. Cox. Lehninger Principles of Biochemistry, $3^{\text {rd }}$ Ed., (Cranbury, N.J: Worth Publishing, 2000).

[8]. SAE practice SAE J1312 procedure for four stroke compressions and spark ignition engines SAE Handbook, Society of Automotive Engineers ( Warrendale, Pennsylvania: SAE publication, 1995).

[9]. TD110-TD115 Test Bed and Instrumentation Manual for Small Engines, (London, TQ Educational and Training Publishers, 2000).

[10]. D.W. Naegeli, P.I. Lacey, M.J. Alger, and D.L. Endicott. Surface corrosion in Ethanol fuel pumps. SAE Paper 971648.1997.

[11]. M. Rizwanul Fattah, H.H. Masjuki, M.A. Kalam, M. Mofijur, M.J., Abedin. Effect of antioxidant on the performance and emission characteristics of a diesel engine fueled with palm biodiesel blends. Energy Convers. Manag. 79, 2014, 265-272.

[12]. B.M. Masum, H.H. Masjuki, M.A. Kalam, S.M. Palash, and M. Habibullah. Effect of alcohol-gasoline blends optimization on fuel properties, performance and emissions of a SI engine. Journal of Cleaner Production, journal homepage: www.elsevier.com/locate/jclepro http://dx.doi.org/10.1016/j.jclepro.2014.08.032 0959-6526/C 2014, Elsevier Ltd. All rights reserved.

[13]. E. Ecklund. Alcohols in diesel engine: A review SAE paper no. 840119. Society of Automotive Engineers. 28 (1), $1984,70-74$.

[14]. K.M. Zoran, and D. D. Gvozdenac. Applied Industrial Energy and Environmental Management. Part III: Fundamentals for Analysis and Calculation of Energy and Environmental Performance. (John Wiley \& Sons, Ltd., 2016) Toolbox 5, http://www.wiley.com/legacy/wileychi/morvayindustrial/supp/toolbox5.pdf Retrieved on 07/09/2016

[15]. Woodgas Densification.Proximate and Ultimate Analysis. Biomass Energy Foundation. http://drtlud.com/BEF/proximat.htm. Retrived on the 07/09/2016

[16]. Shell- Plint Engine Test Bed Manual. (England: Plint and Partners Publications, 1984)..

[17]. P.A.Hubballi, and T.P.A. Babu, Effect of aqueous denatured spirit on engine performance and exhaust emissions, SAE: 280036.,2004.

[18]. C. Carraretto, A. Macor, A. Mirandola, A. Stoppato, and S. Tonon. Biodiesel as alternative fuel, experimental analysis and energetic evaluations. Energy potentials. 29, 2004, 2195-2211.

[19]. M. Alexandrian, and M. Schwalm, Comparison of ethanol and gasoline as automotive fuels. ASME papers 92-WA/ DE-15.1992.

[20]. R.C. Costa, and J.R. Sodre. Hydrous ethanol vs. gasoline-ethanol blend: engine performance and emissions. Fuel 89, 2010, 287-293

[21]. R.M. Bata, A.C. Elord, and R.W. Rice. Emissions from IC engines fueled with Alcohol-gasoline blends: a literature review. Transactions of the ASME 111, 2011, 424-431.

[22]. M. Canakci,A.N. Ozsezen, E. Alptekin, and M. Eyidogan. Impact of alcohol-gasolinelfuel blends on the exhaust emission of an SI engine. Renew. Energy 52, 2013,111-117.

[23]. M. Koç, Y. Sekmen, T. Topgül, and H.S.Yücesu. The effects of ethanol-unleaded gasoline blends on engine performance and exhaust emissions in a spark ignition engine. Renew. Energy 34, 2009, 2101-2106.

[24]. C. Sayin. Engine performance and exhaust gas emissions of methanol and ethanol-diesel blends. Fuel 89, 2010, 3410-3415.

[25]. B.M. Masum, M.A. Kalam, H. Masjuki, S. Palash and I.M. Rizwanul Fattah. Performance and emission analysis of a multi cylinder gasoline engine operating on different alcohol- gasoline blends. RSC Adv. 4 (53), 2014, 27898-27904. 
[26]. ] W. Chan-Wei, C. Rong-Horng, P. Jen-Yung, and L. Ta-Hui.. The influence of air-fuel ratio on engine performance and pollutant emission of an SI engine using ethanol-gasoline-blended fuels. Atmospheric Environment 38,2004,7093-7100

[27]. Y. Yacoub, R. Bata, and M. Gautam. The performance and emission characteristics of C1-C5 alcohol-gasoline blends with matched oxygen content in a single cylinder spark ignition engine. Proc. Instit. Mech. Eng. Part A: J. Power Energy 212, 1998, 363-379.

[28]. B.M.Masum,H.H.Masjuki, M.A. Kalam, I.M. Rizwanul Fattah, S.M., Palash, and M.J. Abedin. Effect of ethanol-gasoline blend on NOx emission in SI engine. Renew. Sustain. Energy Rev. 24, 2013, 209-222.

[29]. B.M.Masum, M.A. Kalam, H.H. Masjuki, and S.M. Palash. Study on the effect of adiabatic flame temperature on NOx formation using ethanol gasoline blend in SI engine. Adv. Mater. Res. 781, 2013, 2471-2475.

\section{Biographies:}

Robinson Ichakpa Ejilah, PhD, is a Senior Lecturer in the Department of Mechanical/Production Engineering, Abubakar Tafawa Balewa University, Bauchi-Nigeria, Former Chief Lecturer and Head of Mechanical Engineering Department, Federal Polytechnic, Bauchi. He is at present a Fellow and Deputy National Chairman, of the Nigerian Institution of Mechanical Engineers (NIMechE). He is also a corporate member of Nigerian Society of Engineers (NSE), Solar Energy Society of Nigeria (SESN), and League of Researchers in Nigeria (LRN). Dr. Ejilah is a Registered Engineer with the Council for the Regulation of Engineering in Nigeria (COREN). He has a penchant for fuel and combustion processes, internal combustion engines, bioenergy, renewable fuels and bio-lubricants research

Tel: +2348057243194; E-mail: irejilah@atbu.edu.ng; rejilah@gmail.com.

Buhari Abubakar Gambo, Assistant Lecturer and $\mathrm{PhD}$ research student in the Department of Mechanical/Production Engineering, Abubakar Tafawa Balewa University, Bauchi- Nigeria. He is a Registered Engineer with the Council for the Regulation of Engineering in Nigeria (COREN). His area of research interest include; fuel and internal combustion systems, renewable energy and bioenergy research.

Tel: +2348032493110; E-mail: gmbuhari@yahoo.com

Kamal Dahuwa, is a Research Fellow I, with the National Center for Petroleum Research and Development, Abubakar Tafawa Balewa University Bauchi Nigeria. He is also a $\mathrm{PhD}$ research student in the Department of Mechanical /Production Engineering, Abubakar Tafawa Balewa University, Bauchi. He is a corporate member of the Nigerian Institution of Mechanical Engineers (NIMechE), and corporate member of the Nigerian Society of Engineers (NSE), and aRegistered Engineer with the Council for the Regulation of Engineering in Nigeria (COREN). His area of research interest is on fuel and internal combustion systems, renewable energy and bioenergy research.

Tel: +2348061555029; E-mail: kmldahuwa@ gmail.com 